Open Access

\title{
Temperatures of storage areas in large animal veterinary practice vehicles in the summer and comparison with drug manufacturers' storage recommendations
}

\author{
Jeff D. Ondrak ${ }^{1 * \dagger}$, Meredyth L. Jones ${ }^{2 \dagger}$ and Virginia R. Fajt ${ }^{3}$
}

\begin{abstract}
Background: Large animal veterinarians carry drugs in their practice vehicles in storage areas that are not typically refrigerated. The most common upper limits of manufacturers' storage temperatures for United States (U.S.)-approved non-refrigerated drugs are 25 or $30^{\circ} \mathrm{C}$. Because ambient temperatures in many locations in the U.S. exceed these temperatures during the summer, we measured storage area temperatures over 4 months in the summer of 2013 to evaluate the extent to which labeled storage temperatures are exceeded.

Methods: A convenience sample of 12 vehicles from 5 central Texas practices and 12 vehicles from 4 south central Nebraska practices was used. Temperatures were recorded in one drug storage compartment in each vehicle from May 15 - September 16, 2013, at 15-minute intervals using a self-contained, battery operated temperature recording device.

Results: The highest temperatures recorded in a storage unit were 54.4 and $47.7^{\circ} \mathrm{C}$ in Texas and Nebraska, respectively. The mean temperature recorded across all 24 storage units was $29.1{ }^{\circ} \mathrm{C}$, with a mean of $26.9^{\circ} \mathrm{C}$ in Nebraska and $31.4^{\circ} \mathrm{C}$ in Texas. In Nebraska, at least one temperature over $25^{\circ} \mathrm{C}$ was recorded on a mean of $111 / 124$ days and a mean of $63 \%$ of total logger readings. In Texas, temperatures over $25^{\circ} \mathrm{C}$ were recorded on a mean of $123 / 124$ days and a mean of $95 \%$ of total logger readings.

Conclusions: Temperatures in storage units in participating veterinary practice vehicles exceeded labeled drug storage temperatures a significant portion of the summer of 2013. More research is needed to determine whether these excursions above the manufacturers' recommended storage temperatures alter efficacy of stored drugs.
\end{abstract}

Keywords: Pharmaceuticals, Drug storage, Large animal practice, Drug stability, Excessive heat

\section{Background}

Large animal veterinarians, those serving horses, cattle, and other livestock, often provide medical care by traveling to farms and other sites where animals are located. The travel vehicle is used to carry equipment, supplies, and drugs, and those items often remain in the truck at all times. These practice vehicles often have after-market storage areas installed, or storage compartments may be built into or added to the inside

\footnotetext{
* Correspondence: jondrak@gpvec.unl.edu

${ }^{\dagger}$ Equal contributors

1 Great Plains Veterinary Educational Center, University of Nebraska-Lincoln, Clay Center, NE, USA

Full list of author information is available at the end of the article
}

of the vehicle. These storage areas may be equipped with small refrigerators and heating capabilities, but generally refrigerator use is limited to items that have manufacturers' requirements for storage at lower than room temperature $\left(20-25^{\circ} \mathrm{C}\right)$ [1].

The U.S. Pharmacopeia (USP) publishes guidelines for the pharmaceutical industry for potency, stability testing, and storage, including temperature. These guidelines apply to all aspects of the supply chain including transport vehicles, which include shipping vehicles and emergency medical service vehicles [2]. These guidelines state that 'temperature is one of the most important conditions to control' [2]. Other environmental

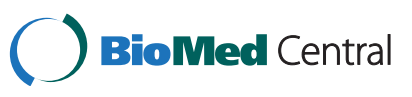

(c) 2015 Ondrak et al. Open Access This article is distributed under the terms of the Creative Commons Attribution 4.0 International License (http://creativecommons.org/licenses/by/4.0/), which permits unrestricted use, distribution, and reproduction in any medium, provided you give appropriate credit to the original author(s) and the source, provide a link to the Creative Commons license, and indicate if changes were made. The Creative Commons Public Domain Dedication waiver (http://creativecommons.org/publicdomain/zero/1.0/) applies to the data made available in this article, unless otherwise stated. 
factors that affect storage stability include light, air, and humidity [3].

Storage temperatures for drugs have been studied in human medical emergency service vehicles [4-7], medical helicopters [8], as well as medical bags [9], and storage container temperature frequently falls outside of label ranges. In a model of stock rotation based on actual measured temperatures in ambulances in five U.S. cities (Topeka, Orlando, Mesa, Portland and Syracuse), excessive heat occurred in all, including the northern cities [10]. Of concern, some emergency medications, including lorazepam [4, 7], have demonstrated instability at real-world ambulance temperatures. In experimental simulation of the ambulance environment, other emergency drugs including epinephrine, lidocaine, diltiazem, dopamine and nitroglycerin experienced a greater than $10 \%$ reduction in concentration, which was correlated with thermal exposure time [11]. Based on the findings of these studies, the USP has added a section to the Good Storage and Distribution Practices for Drug Products which specifically addresses emergency medical service vehicles and other road vehicles used to transport drug products, indicating that temperature monitoring devices should be placed in different areas of the trunk or cabin for monitoring during seasonal extremes [2]. However, these practices do not include specific recommendations for veterinary practice vehicles.

We are acquainted with the storage options and storage practices of large animal veterinarians in the U.S. based on personal experience with practice vehicles (combined we have utilized practice vehicles ourselves from at least 7 different locations, including academic and private practice) and via professional networks. We became concerned that drugs that were stored in nonrefrigerated areas were being subjected to temperatures significantly higher than room temperature. One small study of a veterinary vehicle in England evaluated the temperatures in the car and in a drug storage cabinet within the vehicle, where it was found that the cabinet heated more slowly than did the car, but also cooled more slowly [12], however, we could find no other published studies specific to veterinary practice vehicles.

Our review of drug labels of commonly used drugs in large animal veterinary practice demonstrated that the most common upper limits of storage temperature authorized on drug labels are 25 and $30^{\circ} \mathrm{C}$. Because ambient temperatures in the states in which we currently provide veterinary care consistently exceed these temperature during the summer, the objective of this study was to measure storage area temperatures from May to September, the hottest months of the year, in two distinct geographical areas (central Texas and south central Nebraska), to evaluate the extent to which manufacturers' recommended storage temperatures were exceeded.

\section{Methods}

\section{Selection of practice vehicles}

A convenience sample of 12 vehicles from 5 central Texas veterinary practices and 12 vehicles from 4 south central Nebraska veterinary practices was used. Data on the veterinary practice type, storage unit characteristics, location of the temperature logger within the storage unit, and typical parking locations and conditions of the vehicles were collected with a handwritten survey.

\section{Storage unit temperature recording}

Temperatures were recorded in one drug storage compartment in each vehicle for 124 days from May 15 September 16, 2013, at 15-min intervals using a selfcontained, battery-operated temperature recording device (HOBO Water Temperature Pro v2 Data Logger, Onset Computer Corporation, Cape Cod, MA). The temperature loggers were factory calibrated to $+/-0.2{ }^{\circ} \mathrm{C}$ accuracy.

\section{Ambient temperature source}

Information regarding high and low ambient temperatures for the study period was obtained from Weather Underground $^{1}$ for College Station and Navasota, Texas and Plymouth, Overton and Sutton, Nebraska. All veterinary units were based in locations within a 30 mile radius from one of these data centers.

\section{Descriptive statistics}

Descriptive statistics were performed on the storage temperature data, survey responses and ambient temperature data using commercially available software (Excel, Microsoft Corporation, Redmond, WA and Graph Pad Prism, La Jolla, CA).

\section{Results}

\section{Practice vehicle characteristics}

Twenty four practice vehicles including 23 pick-up trucks with commercially available add-on storage units and one sport utility vehicle utilizing in-cabin storage were enrolled in the project. Participating practices selfidentified by practice type as equine $(n=6)$, large animal $(n=1)$, food animal $(n=4)$, and mixed animal $(n=13)$ (Table 1). Of the 24 practice vehicles participating in this study, 18 of $24(75 \%)$ were subjected to routine unshaded conditions during working hours including 7 of $12(58 \%)$ in Texas and 11 of $12(92 \%)$ in Nebraska. Ten of 24 (42\%) vehicles were maintained in unshaded conditions during non-business hours including 7 of 12 $(58 \%)$ in Texas and 3 of 12 (25\%) in Nebraska.

Small refrigerator units designed to store products specifically labelled for storage under refrigerated conditions and contained within the storage unit were in place and turned on in 8 of the 24 (33\%) practice vehicles including 5 of $12(42 \%)$ in Texas and 3 of $12(25 \%)$ in Nebraska. 
Table 1 Characteristics of participating veterinary practice vehicles and storage units

\begin{tabular}{|c|c|c|c|c|c|c|c|c|c|}
\hline \multirow[t]{2}{*}{ Logger ID } & \multicolumn{2}{|c|}{$\underline{\text { Location }}$} & \multirow[t]{2}{*}{ Practice type } & \multicolumn{4}{|l|}{ Box information } & \multicolumn{2}{|c|}{ Parking conditions } \\
\hline & State & Clinic & & Make & Refrigerator use & Day heater & Heated water & Home/Night & Clinic/Day \\
\hline 22 & $\mathrm{NE}$ & 1 & Mixed & Porta-Vet & No & Off & Off & Unshaded & Unshaded \\
\hline 24 & $\mathrm{NE}$ & 1 & Mixed & Porta-Vet & No & Off & Off & Unshaded & Unshaded \\
\hline 26 & $\mathrm{NE}$ & 2 & Mixed & Bowie & Yes & Off & Off & Garage & Unshaded \\
\hline 36 & $\mathrm{NE}$ & 2 & Mixed & Porta-Vet & No & On & On & Unshaded & Unshaded \\
\hline 43 & $\mathrm{NE}$ & 2 & Mixed & Bowie & No & Off & Off & Garage & Unshaded \\
\hline 51 & $\mathrm{NE}$ & 2 & Mixed & Bowie & Yes & On & On & Garage & Unshaded \\
\hline 58 & $\mathrm{NE}$ & 2 & Mixed & Bowie & Yes & Off & On & Garage & Unshaded \\
\hline 46 & $\mathrm{NE}$ & 3 & Food Animal & Porta-Vet & No & Off & On & Other shade & Unshaded \\
\hline 53 & $\mathrm{NE}$ & 3 & Food Animal & Porta-Vet & No & Off & Off & Garage & Unshaded \\
\hline 57 & $\mathrm{NE}$ & 3 & Mixed & Porta-Vet & No & Off & On & Garage & Unshaded \\
\hline 60 & $\mathrm{NE}$ & 3 & Food Animal & Porta-Vet & No & Off & On & Garage & Unshaded \\
\hline 52 & $\mathrm{NE}$ & 4 & Food Animal & Bowie & No & Off & On & Garage & Garage \\
\hline 33 & TX & 6 & Mixed & Bowie & No & Off & Off & Carport & Carport \\
\hline 44 & TX & 6 & Mixed & Porta $=$ Vet & No & Off & Off & Unshaded & Unshaded \\
\hline 47 & TX & 6 & Mixed & Bowie & No & Off & Off & Unshaded & Unshaded \\
\hline 49 & TX & 6 & Mixed & Porta $=$ Vet & No & Off & Off & Unshaded & Unshaded \\
\hline 56 & TX & 5 & Equine & SUV cargo storage & No & No & No & Unshaded & Unshaded \\
\hline 62 & TX & 5 & Equine & Bowie & No & Off & Off & Tree shade & Tree shade \\
\hline 42 & TX & 7 & Equine & Bowie & Yes & Off & On & Carport & Carport \\
\hline 48 & TX & 7 & Equine & Bowie & Yes & On & On & Carport & Carport \\
\hline 55 & TX & 7 & Large Animal & Bowie & Yes & Off & On & Carport & Carport \\
\hline 40 & TX & 8 & Equine & Stonewell Bodies & Yes & Off & Off & Unshaded & Unshaded \\
\hline 59 & TX & 8 & Equine & Stonewell Bodies & Yes & Off & Off & Unshaded & Unshaded \\
\hline 39 & TX & 9 & Mixed & Bowie & No & Off & Off & Unshaded & Unshaded \\
\hline
\end{tabular}

During the study period 4 of the $24(17 \%)$ storage unit's internal heaters were reported to be set to the on position including 2 of $12(17 \%)$ in Texas and 2 of $12(17 \%)$ in Nebraska. Ten of the 24 participating veterinarians reported utilized the heated water feature of their storage units during the study including 3 of $12(25 \%)$ in Texas and 7 of 12 (58 \%) in Nebraska.

\section{Storage unit temperature readings}

The highest overall temperature recorded in a storage unit was $54.4{ }^{\circ} \mathrm{C}$ in a Texas vehicle and $47.7{ }^{\circ} \mathrm{C}$ in Nebraska (Table 2). The mean high temperatures were 41.3 and $43.9{ }^{\circ} \mathrm{C}$ for Nebraska and Texas, respectively, with the overall mean high temperature of $42.6{ }^{\circ} \mathrm{C}$. The overall mean temperature in storage units was $26.9{ }^{\circ} \mathrm{C}$ in Nebraska and $31.4{ }^{\circ} \mathrm{C}$ in Texas. In Nebraska, at least one temperature over $25^{\circ} \mathrm{C}$ was recorded on a mean of $111 /$ 124 days and a mean of $63 \%$ of total logger readings. In Texas, temperatures over $25{ }^{\circ} \mathrm{C}$ were recorded on a mean of 123/124 days and a mean of $95 \%$ of total logger readings. At least one reading over $30{ }^{\circ} \mathrm{C}$ was recorded a mean of 74/124 days in Nebraska and 117/124 days in Texas.

\section{Frequency and timing of excursions above the recommended storage temperatures}

Figure 1 demonstrates the times of day during which vehicle temperatures exceeded either of the two common recommended drug storage temperatures. The lowest number of excursions above 25 and $30{ }^{\circ} \mathrm{C}$ for Texas loggers were $1242 / 1488$ at $8: 00 \mathrm{AM}$ and $295 / 1488$ at 9:00 AM, respectively (Fig. 1). The highest number of excursions above 25 and $30{ }^{\circ} \mathrm{C}$ for Texas loggers were $1481 / 1488$ from 6:45 to 8:30 PM and 1344/1488 from 6:30 to 6:45 PM, respectively. The lowest number of excursions above 25 and $30{ }^{\circ} \mathrm{C}$ for Nebraska loggers were $540 / 1488$ and 120/1488, respectively, and occurred at 8:45 AM and 9:15 AM. The highest number of excursions above 25 and $30{ }^{\circ} \mathrm{C}$ for Nebraska loggers were $1265 / 1488$ at 6:15 PM and 795/1488 at 6:30 PM. 
Table 2 Temperature logger and ambient temperature summary data

\begin{tabular}{|c|c|c|c|c|c|c|c|c|c|}
\hline Source & Clinic & $\operatorname{Low}\left({ }^{\circ} \mathrm{C}\right)$ & High $\left({ }^{\circ} \mathrm{C}\right)$ & Mean $\left({ }^{\circ} \mathrm{C}\right)$ & $\begin{array}{l}\% \text { readings }> \\
25^{\circ} \mathrm{C}\end{array}$ & $\begin{array}{l}\text { \% days }> \\
25^{\circ} \mathrm{C}\end{array}$ & $\begin{array}{l}\text { \% readings }> \\
30{ }^{\circ} \mathrm{C}\end{array}$ & $\begin{array}{l}\% \text { days }> \\
30^{\circ} \mathrm{C}\end{array}$ & $\begin{array}{l}\text { Total number } \\
\text { of readings }\end{array}$ \\
\hline Logger 22 & 1 & 11.2 & 41.2 & 25.1 & 48.6 & 90 & 18.8 & 57 & 11,904 \\
\hline Logger 24 & 1 & 10.4 & 37.9 & 24.6 & 45.2 & 86 & 15.3 & 50 & 11,904 \\
\hline $\begin{array}{l}\text { Mean for Plymouth-adjacent } \\
\text { loggers }\end{array}$ & & 10.8 & 39.6 & 24.9 & 46.9 & 88 & 17.1 & 53 & 11,904 \\
\hline Plymouth, NE reported temperatures & & 8.8 & 36.7 & 23.7 & 40.3 & 83 & 13.1 & 42 & 8570 \\
\hline Logger 26 & 2 & 11.6 & 42.7 & 28.0 & 70.0 & 92 & 33.2 & 63 & 11,904 \\
\hline Logger 36 & 2 & 8.7 & 43.6 & 24.9 & 47.7 & 88 & 19.9 & 65 & 11,904 \\
\hline Logger 43 & 2 & 11.6 & 43.9 & 27.2 & 68.1 & 94 & 27.5 & 65 & 11,904 \\
\hline Logger 51 & 2 & 15.4 & 47.7 & 32.2 & 95.3 & 100 & 66.3 & 86 & 11,904 \\
\hline Logger 58 & 2 & 15.2 & 42.8 & 29.3 & 82.5 & 98 & 41.8 & 81 & 11,904 \\
\hline Mean Overton-adjacent loggers & & 12.5 & 44.1 & 28.3 & 72.7 & 94 & 37.7 & 72 & 11,904 \\
\hline Overton, NE reported temperatures & & 5.0 & 40.1 & 22.7 & 34.5 & 79 & 12.2 & 46 & 8802 \\
\hline Logger 46 & 3 & 11.2 & 43.7 & 26.8 & 66.7 & 90 & 27.4 & 69 & 11,904 \\
\hline Logger 53 & 3 & 11.2 & 40.5 & 27.2 & 67.2 & 94 & 27.1 & 66 & 11,904 \\
\hline Logger 57 & 3 & 22.3 & 36.7 & 29.2 & 92.9 & 99 & 39.3 & 62 & 11,904 \\
\hline Logger 60 & 3 & 9.9 & 37.5 & 24.8 & 46.2 & 82 & 16.2 & 54 & 11,904 \\
\hline Logger 52 & 4 & 16.1 & 38.1 & 23.6 & 29.9 & 57 & 0.5 & 2 & 11,904 \\
\hline Mean for Sutton-adjacent loggers & & 14.4 & 39.3 & 26.3 & 60.6 & 85 & 22.1 & 51 & 11,904 \\
\hline Sutton, NE reported temperatures & & 6.1 & 36.7 & 22.3 & 30.5 & 77 & 8.3 & 33 & 8822 \\
\hline Logger 33 & 6 & 21.0 & 40.0 & 30.1 & 95.3 & 100 & 47.6 & 88 & 11,904 \\
\hline Logger 44 & 6 & 21.7 & 54.4 & 30.6 & 96.5 & 100 & 52.9 & 92 & 11,904 \\
\hline Logger 47 & 6 & 19.8 & 38.8 & 29.7 & 94.0 & 99 & 44.1 & 82 & 11,904 \\
\hline Logger 49 & 6 & 16.2 & 53.4 & 29.3 & 80.3 & 100 & 4108 & 94 & 11,904 \\
\hline Mean for Navasota-adjacent loggers & & 19.7 & 46.7 & 29.9 & 91.5 & 100 & 46.6 & 89 & 11,904 \\
\hline Navasota, TX reported temperatures & & 18.2 & 41.9 & 29.7 & 85.6 & 100 & 42.4 & 96 & 8880 \\
\hline Logger 56 & 5 & 23.2 & 39.9 & 31.8 & 99.3 & 100 & 72.1 & 98 & 11,904 \\
\hline Logger 62 & 5 & 18.1 & 44.9 & 29.5 & 85.3 & 100 & 42.5 & 97 & 11,904 \\
\hline Logger 42 & 7 & 20.7 & 42.2 & 31.8 & 98.2 & 100 & 64.5 & 96 & 11,904 \\
\hline Logger 48 & 7 & 23.1 & 41.2 & 32.6 & 99.2 & 100 & 80.5 & 98 & 11,904 \\
\hline Logger 55 & 7 & 21.6 & 40.4 & 32.1 & 98.5 & 100 & 71.7 & 97 & 11,904 \\
\hline Logger 40 & 8 & 20.7 & 47.2 & 33.7 & 98.1 & 100 & 74.7 & 98 & 11,904 \\
\hline Logger 59 & 8 & 23.3 & 41.0 & 33.2 & 99.3 & 100 & 86.1 & 98 & 11,904 \\
\hline Logger 39 & 9 & 20.6 & 43.8 & 32.1 & 96.4 & 100 & 63.5 & 98 & 11,904 \\
\hline $\begin{array}{l}\text { Mean for College Station-adjacent } \\
\text { loggers }\end{array}$ & & 21.4 & 42.6 & 32.1 & 96.8 & 100 & 69.5 & 98 & 11,904 \\
\hline $\begin{array}{l}\text { College Station, TX reported } \\
\text { temperatures }\end{array}$ & & 17.0 & 41.1 & 28.2 & 99.1 & 100 & 40.1 & 93 & 3586 \\
\hline NE means for loggers & & 14.6 & 42.7 & 27.7 & 70.4 & 92 & 32.5 & 67 & 11,904 \\
\hline NE means for weather reports & & 6.6 & 37.8 & 22.9 & 35.1 & 80 & 11.2 & 40 & 8731 \\
\hline TX means for loggers & & 20.8 & 43.9 & 31.4 & 95.0 & 100 & 61.8 & 95 & 11,904 \\
\hline TX means for weather reports & & 17.6 & 41.5 & 29.0 & 92.4 & 100 & 41.3 & 94 & 6233 \\
\hline
\end{tabular}

Ambient temperature readings

The highest daily ambient temperature for all Texas locations was $41.9^{\circ} \mathrm{C}$ and for all Nebraska locations was
$40.1{ }^{\circ} \mathrm{C}$ (Table 2). The mean daily temperature for Texas locations was $29.0^{\circ} \mathrm{C}$ and for Nebraska was $22.9^{\circ} \mathrm{C}$ with a mean daily high of 41.5 and $37.8{ }^{\circ} \mathrm{C}$, respectively. 


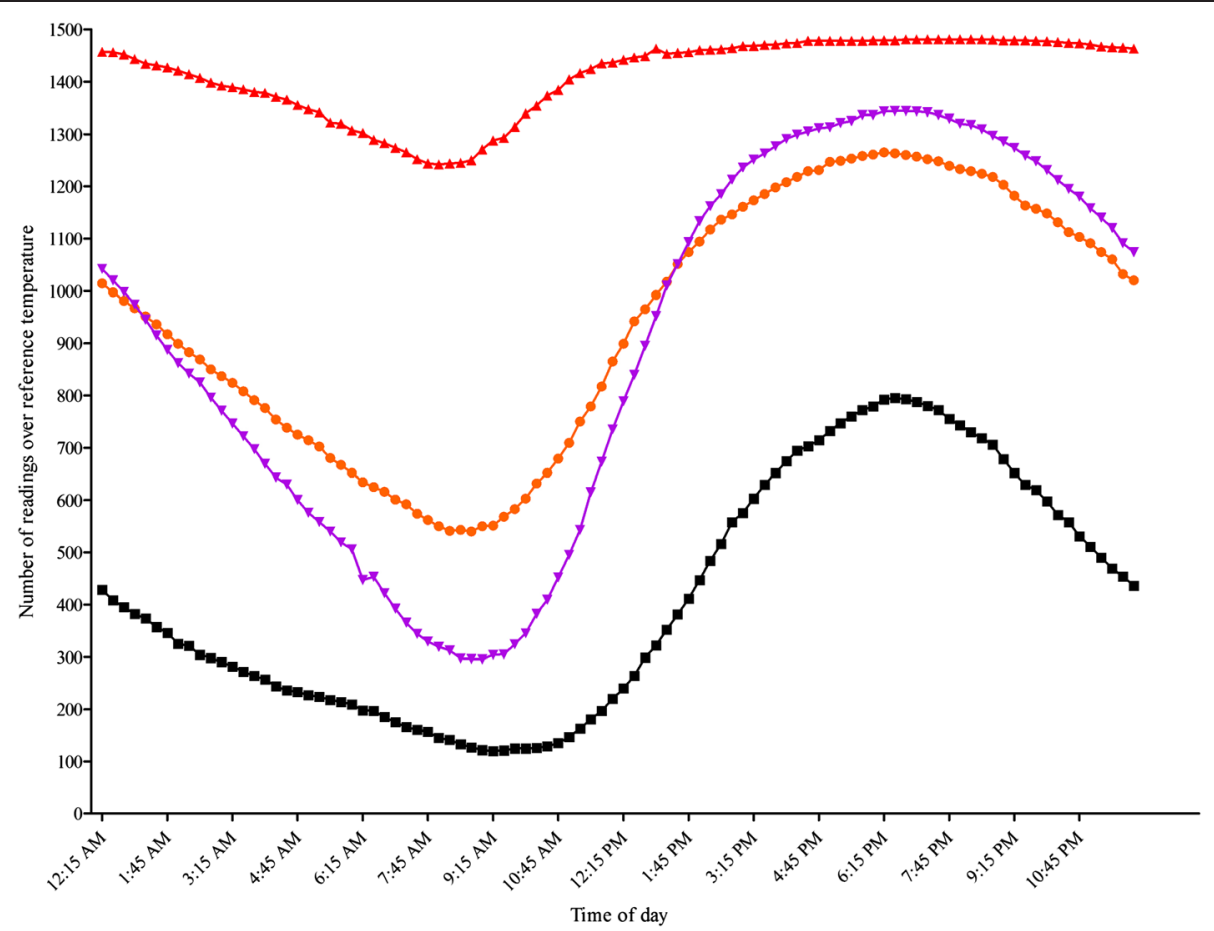

Fig. 1 Frequency of readings exceeding the reference temperatures at each recording time point. - - = Nebraska loggers with readings $>25^{\circ} \mathrm{C}$; $\rightarrow-$ = Nebraska loggers with readings $>30^{\circ} \mathrm{C} ; \boldsymbol{Z}=$ Texas loggers with readings $>25^{\circ} \mathrm{C} ;-=$ Texas loggers with readings $>30^{\circ} \mathrm{C}$

\section{Discussion}

A review of the labels of 58 drugs common on large animal practice vehicles (antimicrobial, antiparasitic, anesthetic, and anti-inflammatory agents, electrolyte solutions, hormones, vitamin/mineral preparations, ophthalmic drugs, and emergency drugs) revealed that the most common maximum temperatures listed on drug inserts for storage of veterinary drugs were 25 and $30{ }^{\circ} \mathrm{C}$. All 58 veterinary drug labels that we reviewed designated an upper limit temperature, with 47 labels citing an upper limit of $30{ }^{\circ} \mathrm{C}, 25$ citing $25{ }^{\circ} \mathrm{C}$ and one citing $40{ }^{\circ} \mathrm{C}$. Only three labels specifically stated that the product is to be protected from heat. There is also one product for which the tolerable temperature range changes after first puncture: the label for tildopirosin (Zuprevo, Merck Animal Health) indicates that the upper temperature limit is $30{ }^{\circ} \mathrm{C}$, but after first puncture is reduced to $25^{\circ} \mathrm{C}$. Some pharmaceutical labels denote that temperature excursions are permitted. The labels of four surveyed products, amprolium (Corid $9.6 \%$ Oral Solution, Merial), ceftiofur hydrochloride (Excenel RTU EZ, Zoetis), sulfamethazine (Sustain III Calf Bolus, Bimeda), and polysulfated glycosaminoglycan (Adequan i.m., Lutipold) state that temperature excursions are permitted, but no temperature or time parameters are provided on the label.

A review was also conducted of the published stability data of drugs of interest in large animal veterinary practice when stored outside the manufacturers' storage recommendations (Table 3). Drugs with demonstrated instability when stored outside of manufacturers' recommendations included two cephalosporin antimicrobial drugs, epinephrine, and oxytocin. No information could be found for the commonly used veterinary drugs xylazine, gonadorelin, and ceftiofur.

The U.S. Pharmacopeia defines controlled room temperature as $20-25{ }^{\circ} \mathrm{C}$. Temperatures between 30 and $40{ }^{\circ} \mathrm{C}$ are considered warm, while excessive heat is defined by the U.S. Pharmacopeia to be temperatures above $40{ }^{\circ} \mathrm{C}$ [1]. For products requiring controlled room temperature storage, temperature spikes up to $40{ }^{\circ} \mathrm{C}$ are permitted if they are transient and less than $24 \mathrm{~h}$ in duration and if the manufacturer allows [13]. Such excursions are permitted by label presumably to allow for transient temperature spikes as may occur during shipping. Temperatures in study vehicles exceed these allowances both in magnitude and duration.

Practices and vehicles within practices were selected for inclusion in this study based on convenience rather than a random sample. Because our goal was descriptive rather than comparative, a sample size assessment was deemed unnecessary. The practice types included likely do not represent the proportion of each practice type in Nebraska or Texas. While practice type may affect the turnover of pharmaceutical inventory in storage units 
Table 3 Reported stability of drugs outside of manufacturers' storage recommendations [11, 15-23]

\begin{tabular}{|c|c|c|}
\hline $\begin{array}{l}\text { Demonstrated to } \\
\text { be stable }\end{array}$ & $\begin{array}{l}\text { Equivocal data about } \\
\text { stability }\end{array}$ & $\begin{array}{l}\text { Demonstrated } \\
\text { to be unstable }\end{array}$ \\
\hline Anesthetics & Anesthetics & Cephalosporins \\
\hline atropine & lidocaine & cefazolin \\
\hline diazepam & naloxone & cephalothin \\
\hline midazolam & Macrolides/lincosamides & Other \\
\hline morphine sulfate & erythromycin & epinephrine \\
\hline phenobarbital & Penicillins/aminopenicillins & heparin \\
\hline Aminoglycosides & amoxicillin $+/$ - clavulanate & oxytocin \\
\hline amikacin & ampicillin & \\
\hline gentamicin & penicillin $\mathrm{G}$ & \\
\hline neomycin & Sulfonamides & \\
\hline Fluoroquinolones & sulfamethoxazole & \\
\hline ciprofloxacin & Tetracyclines & \\
\hline difloxacin & doxycycline & \\
\hline enrofloxacin & tetracycline & \\
\hline marbofloxacin & Other & \\
\hline norfloxacin & dopamine & \\
\hline orfloxacin & furosemide & \\
\hline \multicolumn{3}{|l|}{ Macrolides/lincosamides } \\
\hline \multicolumn{3}{|l|}{ clindamycin } \\
\hline \multicolumn{3}{|l|}{ lincomycin } \\
\hline \multicolumn{3}{|l|}{ tilmicosin } \\
\hline \multicolumn{3}{|l|}{ tulathromycin } \\
\hline \multicolumn{3}{|l|}{ tylosin } \\
\hline \multicolumn{3}{|l|}{ Penicillins } \\
\hline \multicolumn{3}{|l|}{ oxacillin } \\
\hline \multicolumn{3}{|l|}{ cloxacillin } \\
\hline \multicolumn{3}{|l|}{ Sulfonamides } \\
\hline \multicolumn{3}{|l|}{ sulfadimethoxine } \\
\hline \multicolumn{3}{|l|}{$\begin{array}{l}\text { sulfamethoxazole/ } \\
\text { trimethoprim }\end{array}$} \\
\hline \multicolumn{3}{|l|}{ Tetracyclines } \\
\hline \multicolumn{3}{|l|}{ chlortetracycline } \\
\hline \multicolumn{3}{|l|}{ oxytetracycline } \\
\hline \multicolumn{3}{|l|}{ Other } \\
\hline \multicolumn{3}{|l|}{ calcium chloride } \\
\hline \multicolumn{3}{|l|}{ dexamethasone } \\
\hline \multicolumn{3}{|l|}{ diphenhydramine } \\
\hline sodium bicarbonate & & \\
\hline thiamine & & \\
\hline
\end{tabular}

Excluded drugs include extemporaneous solutions, temperature ranges significantly different than those encountered in veterinary practice, and drugs in tissues such as urine or meat due to differences in the seasonality of cases, it would not be expected to influence the temperature profiles experienced in the storage units themselves.

Interestingly a majority, 18 of 24 , of practice vehicles in this study were subjected to routine unshaded conditions during working hours including the time spent parked at the clinic. Conditions described as home/night were slightly better with only 10 of 24 vehicles not shaded during this time. The lack of shade for the vehicles may certainly have played a role in the temperature profiles recorded during this study.

The use of three optional features of the storage units were queried in the survey; refrigerators, day heaters, and heated water, because their use could contribute to increased temperatures within the units. Small, optional refrigerators may be purchased with the storage units and are contained within the larger storage area to store products specifically labeled for storage under refrigerated conditions. Day heaters are another optional feature of the storage units which are typically used only during periods of cold weather to heat the entire storage area to prevent exposing the stored products to unnecessarily cold or freezing temperatures. Most storage units have the capability to supply heated water for the veterinarian's use. The storage unit's hot water reservoir is heated by the vehicle's cooling system if the heating system is turned on. The purpose of describing the use of these three optional features was to provide insight into relative frequency of their use and to highlight them as potential heat sources within the storage units. Analysis of the relationship of these features and the temperatures within the storage units was outside the scope of this study.

The study time period, May 15 to September 15, was selected to coincide with the summer months to provide the highest potential temperature exposures and in the experience of the authors, a time of year in many large animal practices when practice vehicle pharmaceutical inventory experiences a slow turnover due to decreased case loads. The results of the study, therefore, may represent a worst case scenario for pharmaceutical storage.

As expected the highest temperatures recorded in the storage units were recorded at locations in Texas. However, mean temperatures recorded by Nebraska temperature loggers were over the $25{ }^{\circ} \mathrm{C}$ labelled upper limit storage temperature of many commonly used pharmaceuticals. Of even more concern is that the mean temperatures recorded by Texas temperature loggers were over the $30{ }^{\circ} \mathrm{C}$ labelled upper limit storage temperature of certain pharmaceuticals. Additionally, a large number of days with at least one recorded temperature exceeding the reference temperatures and a large number of individual recordings exceeding the reference temperatures were recorded in both states. These findings indicate pharmaceuticals maintained in practice 
vehicle's storage units were exposed to temperatures above their labelled storage range a significant portion of the time during the summer months in both Nebraska and Texas. These findings are consistent with a similar study in Austria which evaluated drug-compartment temperatures in car, van, and utility veterinary practice vehicles [14].

The frequency of excursions above 25 and $30{ }^{\circ} \mathrm{C}$ for Texas and Nebraska loggers as shown in Fig. 1 followed a consistent pattern with the lowest frequency occurring in the mid-morning hours and highest frequency of excursions occurring in the early evening hours. However, it is important to note that multiple excursions over both reference temperatures occurred at all of the 96 daily time points. This indicates the need for implementation of practices which will reduce heat accumulation in portable veterinary units throughout the day, but particularly during the late afternoon and early evening hours.

Analysis of the relationship between ambient temperatures and temperatures within the storage boxes was outside the objective of this study. Local ambient temperatures were provided to serve as a reference to the conditions encountered by the storage units. However, it is interesting to note the temperatures recorded in the storage units consistently exceeded the environment temperatures suggesting a greenhouse effect in the storage unit which may have been exacerbated by a lack of shade.

\section{Conclusions}

Temperatures in drug storage units in participating Nebraska and Texas veterinary practice vehicles routinely exceeded labelled drug storage temperatures. Vehicles were routinely left unprotected from direct sunlight and utilized one or more optional features which may have contributed to these findings. More research is needed to determine whether these excursions alter efficacy of stored drugs or lead to degradation products which may pose a health risk to the patient or eventually the consumer. However, until more data are available, veterinarians should consider whether maintaining drug inventories above manufacturers' labeled temperatures may leave them at risk of liability for potential consequences of using drugs stored under these conditions. Furthermore, veterinarians should consider providing shade to their practice vehicles and employing judicious use of optional features such as intra-unit refrigerators, day heaters, and heated water while monitoring the temperatures within their storage units to reduce the occurrence of excursions over the labelled storage temperatures.

\section{Endnote}

${ }^{1}$ www.wunderground.com

\section{Abbreviations}

U.S.: United States; USP: United States Pharmacopeia.

\section{Competing interests}

All authors declare that they have no competing interests.

\section{Authors' contributions}

JO conceived the study, conducted the survey and placement/retrieval of loggers in Nebraska, and collated and analyzed the logger data. MJ conceived the study, conducted the survey and placement/retrieval of loggers in Texas, and collated truck demographic information, weather data, and drug label information. VF initiated the collaboration, collated drug stability literature, and contributed to interpretation of results. All authors participated in the design of the study and drafting of the manuscript. All authors read and approved the final manuscript.

\section{Authors' information}

Not applicable.

\section{Acknowledgements}

This study was supported by internal funds from the University of Nebraska-Lincoln and Texas A\&M University. The authors would like to thank Dr. Tami M. Brown-Brandl, USDA-ARS U.S. Meat Animal Research Center, for the use of the temperature loggers. We also wish to thank the veterinary practitioners who allowed for placement of temperature loggers in their practice vehicles.

Preliminary results from this study were presented as a Research Summary at the 47th Annual Conference of the American Association of Bovine Practitioners, Albuquerque, New Mexico, Sept. 18-20, 2014.

\section{Author details}

${ }^{1}$ Great Plains Veterinary Educational Center, University of Nebraska-Lincoln, Clay Center, NE, USA. ${ }^{2}$ Large Animal Clinical Sciences, Texas A\&M University College of Veterinary Medicine and Biomedical Sciences, College Station, TX USA. ${ }^{3}$ Veterinary Physiology and Pharmacology, Texas A\&M University College of Veterinary Medicine and Biomedical Sciences, College Station, TX, USA.

Received: 4 February 2015 Accepted: 25 September 2015

Published online: 01 October 2015

\section{References}

1. U.S. Pharmacopeia. General Notices and Requirements Applying to Standards, Tests, Assays, and Other Specifications of the United States Pharmacopeia. USP 33-NF 28 Reissue. [http://www.usp.org/sites/default/ files/usp_pdf/EN/USPNF/USP33-NF28-ReissueGeneralNotices.pdf]. Accessed on September 30, 2015.

2. U.S. Pharmacopeia: General Notices and Requirements Applying to Standards, Tests, Assays, and Other Specifications of the United States Pharmacopeia. USP 32. [http://www.usp.org/sites/default/files/usp_pdf/EN/USPNF/ generalNoticesandRequirementsFinal.pdf]. Accessed on September 30, 2015.

3. U.S. Department of Health and Human Services: Guidance for Industry \#5 Drug Stability Guidelines. [http://www.fda.gov/downloads/animalveterinary/ guidancecomplianceenforcement/guidanceforindustry/ucm051556.pdf]. Accessed on September 30, 2015.

4. Gottwald MD, Akers LC, Liu PK, Orsulak PJ, Corry MD, Bacchetti P, et al. Prehospital stability of diazepam and lorazepam. Am J Emerg Med. 1999;17:333-7.

5. DuBois WC. Drug storage temperatures in rescue vehicles. J Emerg Med. 2000;18:345-8

6. Helm M, Castner TH, Lampl L. Environmental temperature stress on drugs in prehospital emergency medical service. Acta Anaesthesiol Scand. 2003; $47: 425-9$

7. De Winter S, Vanbrabant P, Vi NT, Deng X, Spriet I, Van Schepdael A, et al. Impact of temperature exposure on stability of drugs in a real-world out-of-hospital setting. Ann Emerg Med. 2013:62:380-7.

8. Szucs P, Allegra JR, Fields LA, Grabiner FR, Lavery R, Prusik T, et al. Storage temperatures of medications on an air medical helicopter. Air Med J. 2000;19:19-21.

9. Rudland SV, Jacobs AG. Visiting bags: a labile thermal environment. BMJ. 1994;308:954-6. 
10. Brown LH, Wojcik SM, Bailey LC, Tran CD. Can stock rotation effectively mitigate EMS medication exposure to excessive heat and cold? Am J Emerg Med. 2006;24:14-8

11. Gammon DL, Su S, Jordan J, Patterson R, Finley PJ, Lowe C, et al. Alteration in prehospital drug concentration after thermal exposure. Am J Emerg Med. 2008;26:566-73.

12. Summerhays GES. Monitoring of temperature in cars with regard to the pharmaceutical precautions of medicine storage. Eq Vet Educ. 2000;12:307-11.

13. U.S. Pharmacopeia: General Notices and Requirements Applying to Standards, Tests, Assays, and Other Specifications of the United States Pharmacopeia. USP 34. [http://www.usp.org/sites/default/files/usp_pdf/EN/USPNF/USP34-NF29 General\%20Notices.pdf]. Accessed on September 30, 2015.

14. Haberleitner A, Schauberger G, Horak J, Schmerold I. Thermal drug storage conditions in veterinary vehicles - a one-year field study in Austria. Wiener Tierärztliche Monatsschrift. 2014;101:110-9.

15. Valenzuela TD, Criss EA, Hammargren WM, Schram KH, Spaite DW, Meislin HW, et al. Thermal stability of prehospital medications. Ann Emerg Med. 1989;18:173-6.

16. Traub WH, Leonhard B. Heat stability of the antimicrobial activity of sixty-two antibacterial agents. J Antimicrob Chemother. 1995;35:149-54.

17. Ballereau F, Prazuck T, Schrive I, Lafleuriel MT, Rozec D, Fisch A, et al. Stability of essential drugs in the field: results of a study conducted over a two-year period in Burkina Faso. Am J Trop Med Hyg. 1997;57:31-6.

18. McMullan JT, Pinnawin A, Jones E, Denninghoff K, Siewart N, Spaite DW, et al. The 60-day temperature-dependent degradation of midazolam and lorazepam in the prehospital environment. Prehosp Emerg Care. 2013;17:1-7.

19. Berendsen BJ, Elbers IJ, Stolker AA. Determination of the stability of antibiotics in matrix and reference solutions using a straightformward procedure applying mass spectrometric detection. Food Addit Contam Part A Chem Anal Control Expo Risk Assess. 2011;28:1657-66.

20. Concannon J, Lovitt H, Ramage M, Tai LH, McDonald C, Sunderland VB. Stability of aqueous solutions of amoxicillin sodium in the frozen and liquid states. Am J Hosp Pharm. 1986;43:3027-30.

21. Sylvestri MF, Makoid MC. Stability of ampicillin trihydrate suspension in amber plastic oral syringes. Am J Hosp Pharm. 1986;43:1496-8.

22. Nicholas E, Hess G, Colton HR. Degradation of penicillin, ticarcillin, and carbenicillin resulting of unit doses. N Eng J Med. 1982;306:547-8.

23. Injac R, Djordjevic-Milic V, Srdjenovic B. Thermostability testing and degradation profiles of doxycycline in bulk, tablets, and capsules by HPLC. J Chromatogr Sci. 2007:45:623-8.

\section{Submit your next manuscript to BioMed Central and take full advantage of:}

- Convenient online submission

- Thorough peer review

- No space constraints or color figure charges

- Immediate publication on acceptance

- Inclusion in PubMed, CAS, Scopus and Google Scholar

- Research which is freely available for redistribution 